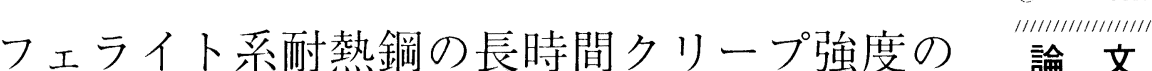 基本特性

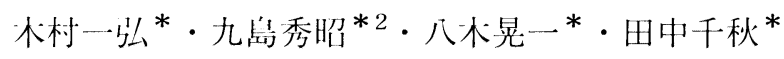

\section{Fundamental Properties of Long-term Creep Strength for Ferritic Heat Resistant Steels}

\author{
Kazuhiro Kimura, Hideaki Kushima, Koichi YagI and Chiaki TanaKa
}

\begin{abstract}
Synopsis :
In view of inverse sigmoidal form of stress $v s$. time to rupture curve, long-term creep strength of ferritic heat resistant steels has been investigated using a large number of long-term creep data in the NRIM Creep Data Sheets. It was observed that the inverse sigmoidal form of stress vs. time to rupture curve was caused not by the change in mechanisms of strengthening or deformation, but by the decrease in creep strength and by the approach to steady internal stress due to microstructural change. At lower stresses, the complex form of creep rate $v s$. time curve which had two minima in creep rate was found and attributed to the inverse sigmoidal form of stress vs. time to rupture curve. Comparing the creep rupture strength for the different kind of steels, the large difference in creep rupture life of about four orders of magnitudes was found at lower temperatures and higher stresses. At higher temperatures and lower stresses, however, the creep rupture strength of all ferritic steels investigated was almost the same. It was concluded that the creep strength of the ferritic heat resistant steels was reduced by the microstructural change and approached to the inherent values which were nearly the same for all ferritic steels investigated. Key words : creep; creep rupture strength; ferritic heat resistant steel; microstructural change; stress $v s$. time to rupture curve; inverse sigmoidal form; inherent value of creep strength.
\end{abstract}

\section{1. 緒}

言

老杪化した火ノ発電設備の制令が年々増加するのに伴 い，现们没備の序分を延长させることの要求も高まりつ つある。これに忍えるためには，各構迶部材の経年少化 の程度を的確に把握し，余待命を精度艮く予测する必要 がある。これらの現状を踏まえて高温構造部材の高温, 長時䦌使用に伴う旗度低下の機構を解明しようとする研 究が最近励発に行われてきた1)ー22). 例えば，蒸気夕一 ビンローターとして使用される $\mathrm{Cr}-\mathrm{Mo}^{-} \mathrm{V}$ 鋼において は，旧オーステナイト档界近傍で優先的に生ずる回復 現象が20121，またボイラーチューブ管に用いられる SUS304においては $\sigma$ 相の粆界析惊によって粒界上の $\mathrm{M}_{23} \mathrm{C}_{6}$ 岑化物が消滅し, $\mathrm{M}_{23} \mathrm{C}_{6}$ の粒界析出強化量の低 下がクリープ抵抗を低下させること到が明らかにされ

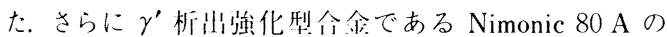
高温产時䦌使用によるクリープ抵抗の低下には $\gamma^{\prime}$ 相に
よる粒界析出強化量の低下もまた重要であること蛙が 指摘されている，以上のように，いくつかの材料につい ては材所劣化を招く機構に関する知見が蓄積されつつあ るが, ある程度広い範井の鋼種にわたって組織变化に伴 う強度低下を系統的に把握し，長時間側でのクリープ少充 度を资量的に評価及び推分するといった報告はほとんど ない.

言時閆クリープ強度, 特に破断強度を推定する場仝に は，比較的短時閏のデー夕に基づいたパラメーター外抑 法が用いられる23). 外挿法としては, Larson-Miller, Orr-Sherby-Dorn, Manson-Succop, Manson-Haferd 及び Manson-Brown 法などが提案されてきたが，长時 閏破断強度を精度よく推足しうる手法はいまだないと いってよい，長時間破断強度の外挿を网難にする最も人 きな要因は組織変化に基づいて生ずるそれぞれの鋼種特 行の忍力ー破断時閒曲線を推走できないことによる，忙 力ー破断時間曲線の勾配は長時間側で連続的に生じる材



* 金禹材料技術研究沂 1.博 (National Research Institute for Metals)

*2 金禹材料技術研究们 (National Research Institute for Metals, 2-3-12 Nakameguro Meguro-ku, Tokyo 153) 
筫少化により徐々に增大する場介がほとんどである。し かし，フェライト系臫熱艄に抢いては，忍打一破断時 测曲線に出曲が化じ，曲線の约配が主时间側で小さく

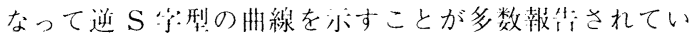

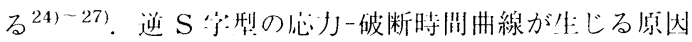


が異なることにあると考えられてきた。すなわち，州曲 が牛じる前に働いていた浊化機構がある時䦌域で効果が 減少するため伈了一破断時间曲線の公配が大きくなって

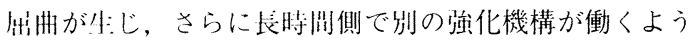
になってくるため幻配が特び減少して、尖值になると考 えら机てきた。またここの忍う一破断時䦌曲線の公配の 変化と间様，クリープ速度の㤁指数， $n$ 储が变化する ことも指摘され，この場令， $n$ 值の変化をクリープの変 形機構の変化として説明した派留もある 28 - 30).

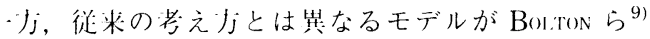
によって提案された。すなわち，Fig. 1 にホすように， 智時洞側で組織変化がない $\left(S_{1}=S_{1}^{0}\right)$ と想足した場令,

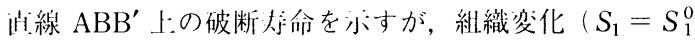
$\left.\rightarrow S_{1}^{f}\right)$ により強度が低下する時闍域ではクリープ大年命 は㨁線 BC 上を遷移し，忍少一破断時䦌曲線の公配が増 人する。しかし，より长時阔側では微細組織が热全に焼 きなまされた，あるいは焼きもどされた䓎是な状態 $\left(S_{1}=S_{1}^{f}\right)$ になるため, 尚線 C'CD に沿ったクリープ 主父をホし，忠う一破断時䦌曲線の勾配が小さくなる。 このように，逆S 字型の曲線にみられる䖵曲は，例え ば成化物による析计分散活化量の低下といった組織変化

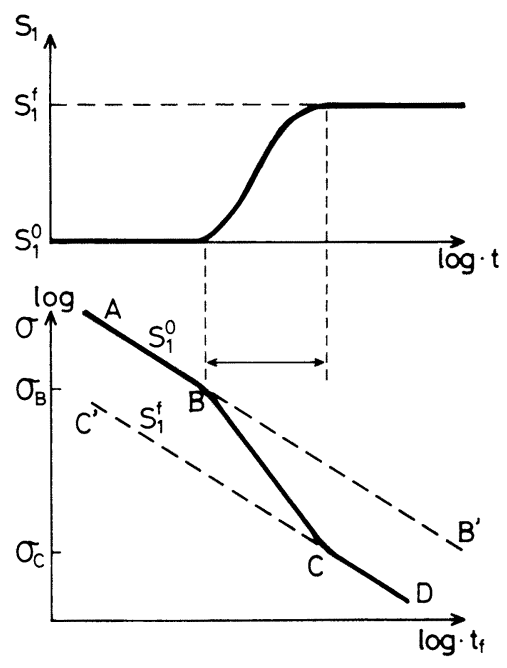

Fig. 1. Schematic representation concerning the effect of thermally induced microstructural changes on creep life $\mathrm{e}^{\text {! }}$.

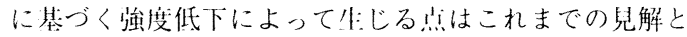

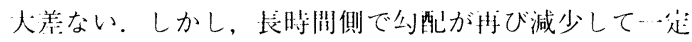
值になるのは，別の㧛化機構が働くようになったため


によるとした哭はこれまでの見解とは人きく異なる。 BOLTONらのモデルを支持する研究成果が, 最近 $\mathrm{Al}$ 众 金に関して報渻された ${ }^{31)}$ 。しかし、フェライト系舺熱 銅の忍力一破断時閶曲線が逆 S 等の形状を牛ずる機 構がBoI.TONらのモデルで竞明された例はない。㚇力一 破断時閏曲線において舞曲が代ずる機構を解明すること は，長時閏クリープ㺈度の経時変化を的確に把握するの みならず，新材料の開発に対しても仿用な指針を迈える ものと思われる。

そこで本研究では, フェライト系拊熱鋼のクリープ独 度の辰時閏にわたる経時变化を的確に把握することを目 的として，金材技研クリープデータシートの龙人な量の クリープ破断デー夕を用い，伈了一破断時䦌曲線が逆 $\mathrm{S}$ 宁型の形状を示すようになる機構を検湖した。

\section{2. 実 験 方 法}

本研究で用いた供武材は食材技研クリープデータシー トの中から選んだ $0.5 \mathrm{Mo}$ 鎆から $12 \mathrm{Cr}-1 \mathrm{Mo}^{-1} \mathrm{~W}$ 鋼ま での 10 種類のフェライト铜で, 齐鋼種とも米均的ク リープ溞度を示すヒートである。強度詊価に用いた Larson-Miller パラメーター (以後, LMP と標瓶する) には起数として 20 を使用した。

$0.5 \mathrm{Cr}-0.5 \mathrm{Mo}$ 鋼のクリープ破断材については武験片 平行部縦断面の光学:顕微鏡及び透過電子顕微鏡による組 織観祭とフェライト精内の硬さ測分をを行った。光学顕微 鏡観祭用試料の候食液にはナイタルを用い，透過電子·湿 微鏡観祭用薄膜試料は放電加ににより徜径 $3 \mathrm{~mm}$ のディ スク状試料を切り出した後， $10 \%$ 過塩素酸アルコール 溶液を用いて，双ジェット電解研磨により作製した。 フェライト粒内の硬さにはマイクロビッカース硬さ試験



\section{3. 実験結果及び考察}

\section{$3 \cdot 10.5 \mathrm{Cr}-0.5 \mathrm{Mo}$ 鋼の長時間クリープ強度}

$723 ， 773 ， 823$ 及び $873 \mathrm{~K}$ における $0.5 \mathrm{Cr}-0.5 \mathrm{Mo}$ 鋼 の忍力-破断時間曲線を Fig. 2 にふす。. 723 及び $773 \mathrm{~K}$ においては破断時開の増加に伴い曲線の公配は単淍に増 大寸る。しかし， $823 \mathrm{~K}$ における曲線の公配は知時䦌側 では破断時間の増加に伴い増火するが，忘力が約 100 $\mathrm{MPa}$ 以下，破断時䦌が約 $10000 \mathrm{~h}$ を超えると，逆に小






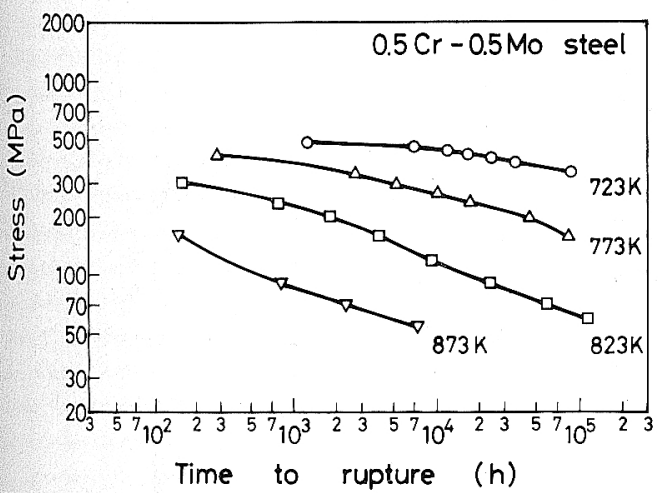

Fig. 2. Stress vs. time to rupture curves of $0.5 \mathrm{Cr}^{-}$ $0.5 \mathrm{Mo}$ steel at $723,773,823$ and $873 \mathrm{~K}$.

約 $100 \mathrm{MPa}$ 以下になると曲線の勾配は減少して，823 K の舞特間側の直線とほぼ平衍になる。

Fig. 2 の絬果を LMP で整理すると, $723 \mathrm{~K}$ から 873 K までのすべての試験紹果が一本の曲線で整理された。 曲線の勾狍は LMP の値の増加に伴い増大したが，Fig. 2 の綃果同様灾力が約 $100 \mathrm{MPa}$ 以下，すなわち LMP 值としては約 20000 以上になると曲線の勾配が小さく なり，曲線の形状は逆 S 字型の挙動が明確に認められ t.

Fig. 2 の応力-破断時間曲線に扮いて逆 $\mathrm{S}$ 尔型の举動
が認められた $823 \mathrm{~K} に$ に执いて，約 200，2000，20000 及び最長の $110000 \mathrm{~h}$ で破断した試料の光学顕微鏡組 織をPhoto. 1 に示す。最も短時間の約 $200 \mathrm{~h}$ 破断材(a) フェライト十パーライト組織であり，受入れ材と比べ 明確な組織变化は光顕の範囲では認められなかった。し かし，約 $2000 \mathrm{~h}$ 破断材（b) ではフェライト粒内に炭 化物がわずかに析出している. 約 $20000 \mathrm{~h}$ 破断材 (c) では，フェライト粒内に多量の炭化物が析出するととも に，パーライト領域では炭化物がまばらになり，層状組 織が壤れている。また，粒界上の炭化物はかなり粗大化 している，最も長時間の約 $110000 \mathrm{~h}$ 破断材（d)では フェライト粒内の炭化物の粗大化とパーライト組織の破 壊がさらに進行しており，フェライト粒とパーライト領 域との判別が困難である。

本供試鋼のようにフェライト，パーライトの二相混合 組織では，変形の大半はフェライト粒で生じていると思 われる。 そこで Photo. 1 と同一の試料のフェライト粒 内の透過電顕組織を Photo. 2 に示す。最も短時間の約 $200 \mathrm{~h}$ 破断材 (a) では転位密度が著しく高く, $0.1 \mu \mathrm{m}$ 以下の微紐な炭化物の析出が認如られる。約 $2000 \mathrm{~h}$ 破 断材（b）では転位密度は若干低下しており，また，多 量の粒状炭化物の析出が明確に認妨られ。伈力一破断 塍閒曲線の勾配が再び小さくなる時閒域にある約 $20000 \mathrm{~h}$ で破断した試料（c）では粒状の炭化物に加え，
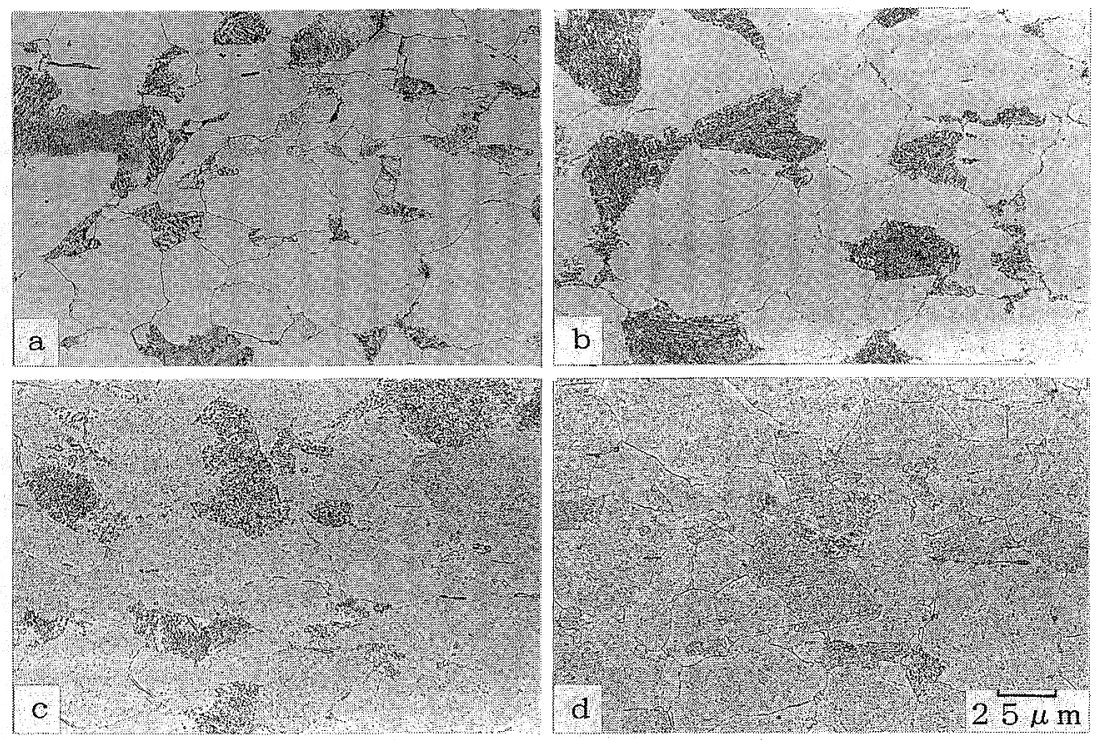

$$
\begin{array}{ll}
\text { a : } \sigma=294 \mathrm{MPa}, t_{r}=155.8 \mathrm{~h} & \mathrm{~b}: \sigma=196 \mathrm{MPa}, t_{r}=1778.3 \mathrm{~h} \\
\mathrm{c}: \sigma=88 \mathrm{MPa}, t_{r}=23788.3 \mathrm{~h} & \mathrm{~d}: \sigma=59 \mathrm{MPa}, t_{r}=112776.4 \mathrm{~h}
\end{array}
$$

Photo. 1. Optical micrographs of $0.5 \mathrm{Cr}-0.5 \mathrm{Mo}$ steel ruptured at $294,196,88$ and $59 \mathrm{MPa}$ and $823 \mathrm{~K}$. 



a : $\sigma=294 \mathrm{MPa}, t_{r}=155.8 \mathrm{~h} \quad$ b: $\sigma=196 \mathrm{MPa}, t_{r}=1778.3 \mathrm{~h}$

c: $\sigma=88 \mathrm{MPa}, t_{r}=23788.3 \mathrm{~h} \quad \mathrm{~d}: \sigma=59 \mathrm{MPa}, t_{\mathrm{r}}=112776.4 \mathrm{~h}$

Photo. 2. Transmission electron micrographs of $0.5 \mathrm{Cr}-0.5 \mathrm{Mo}$ steel ruptured at 294 , 196,88 and $59 \mathrm{MPa}$ and $823 \mathrm{~K}$.

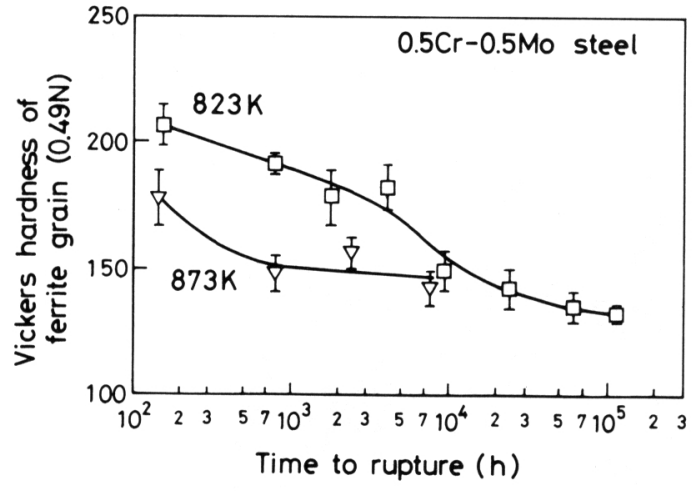

Fig. 3. Changes in Vickers hardness of ferrite grain for $0.5 \mathrm{Cr}-0.5 \mathrm{Mo}$ steel ruptured at 823 and $873 \mathrm{~K}$.

$\mathrm{Mo}_{2} \mathrm{C}$ と推定される針状炭化物が多量に析出しており, 転位密度は著しく低下している。最長の約 $110000 \mathrm{~h}$ で 破断した試料（d）では炭化物の粗大化がさらに進行し ており, 転位密度も低い。

823 及び $873 \mathrm{~K}$ 破断材のフェライト粒内の硬さと破断 時間との関係を Fig. 3 に示す。いずれの試験温度にお いても破断時間の増加に伴いフェライト粒内の硬さは減 少するが, $823 \mathrm{~K}$ では約 $10000 \mathrm{~h}$ をまた $873 \mathrm{~K}$ では
約 $1000 \mathrm{~h}$ を超えるとそれ以上硬さは減少せず, 一定值 を示す．硬さが一定值を示す時間域は，いずれの試験温 度においても，忍力-破断時間曲線の勾配が小さく，ま た直線的になる時間域 (Fig. 2) とほぼ一致している. したがって, $823 \mathrm{~K}$ では約 $10000 \mathrm{~h}$ を, $873 \mathrm{~K}$ では約 $1000 \mathrm{~h}$ を超えると析出炭化物の粗大化により析出強化 の効果が消失し, 強度がそれ以上低下しない一定レベル に到達し，そのため応力-破断時間曲線の勾配が小さく なり, 逆 $\mathrm{S}$ 字型の形態を呈したものと考えられる.

以上の結果をまとめて時間に伴う組織因子の変化とそ れに対応した強化量 (変形抵抗) の変化及び忍力-破断 時間曲線の形態を Fig. 4 に模式的に示した。 な拉，強 化量を表すパラメーターとして変形抵抗を推測する内部 応力を用いている．従来，フェライト系鋼に扰いて多数 報告されてきたように，0.5Cr-0.5Mo 鋼においても， その応力-破断時間曲線は逆 $\mathrm{S}$ 字型の形状を示した。破 断材の組織観察及び硬さ測定結果より, 析出炭化物の粗 大化という組織変化によって炭化物による析出分散強化 量がある時間を超えると急激に低下し，それに対忍して 内部応力が低下する. さらに長時閣側では析出分散強化 量はほとんど消失し, 内部応力がそれ以上低下しない一 定值に達したために，応力一破断時間曲線が逆 $\mathrm{S}$ 字型の 形態を呈したものと推察した。すなわち，忍力一破断時 


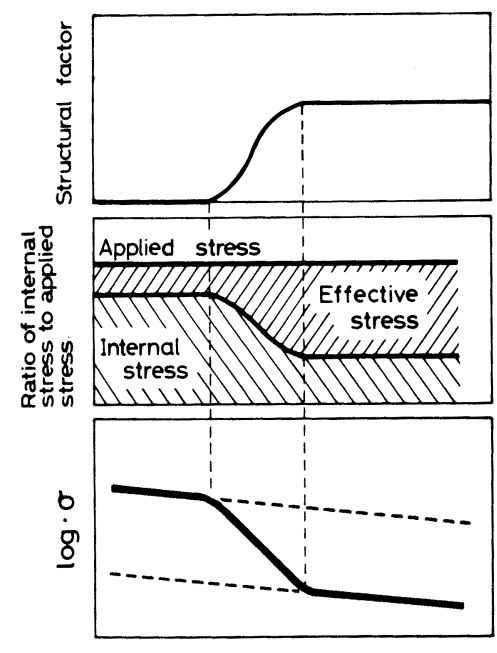

$\log \cdot t$

Fig. 4. Schematic representation concerning the effects of thermally induced microstructural changes on internal stress and creep life.

間曲線が逆 $\mathrm{S}$ 字型の形状を呙したのは従来の多くの報 告にあるように，二つの強化機構の働く時間域が異な ること，あるいは変形機構が変化するのではなく， BoLToN らのモデルと同様炭化物の粗大化という組織変 化に基づいて，析出分散強化という一つの強化機構が働 かなくなり，マトリックスの強度（以後基底強度と呼ぶ） によってのみクリープが支えられるようになったために 生したものと推論した。

\section{$3 \cdot 2$ 逆 $\mathrm{S}$ 字型遷移とクリープ变形挙動}

前節では $0.5 \mathrm{Cr}-0.5 \mathrm{Mo}$ 鋼のクリープデータについて 㛟討を行い，析出炭化物の粗大化に伴い析出分散強化量 が低下して基底強度に達したため, 逆 $\mathrm{S}$ 字型の応力一破 断時間曲線が现出したものと推祭した.そこで本節では， $0.5 \mathrm{Cr}-0.5 \mathrm{Mo}$ 鋼と间様, 逆 $\mathrm{S}$ 字型の応力-破断時間曲 線が明確に認められる $1.25 \mathrm{Cr}-0.5 \mathrm{Mo}-\mathrm{Si}$ 鋼について, 他力一破断時間曲線が逆 S 型を示すクリープ破断条件 下のクリープ変形挙動について検討を行う。

$1.25 \mathrm{Cr}-0.5 \mathrm{Mo}-\mathrm{Si}$ 鋼の $773 ， 823 ， 873$ 及び $923 \mathrm{~K}$ に おける於力一破断時閌曲線を Fig. 5 に示す。 773 及び $823 \mathrm{~K}$ では逆 S 学型の挙動が明確に認められる。すな

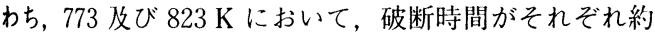
$10000 \mathrm{~h}$ 及び約 $500 \mathrm{~h}$ に抢いて長時間側の安定状態に対 伈した勾配の小さな稙線領域へと遷移している。な㧍， 873 及び $923 \mathrm{~K}$ では破断時間がそれぞれ約 5000 及び $500 \mathrm{~h}$ を超えた长時間側で急激な寿命低下が認められる が、これは試験片の酸化の程度が著しいため, 酸化によ

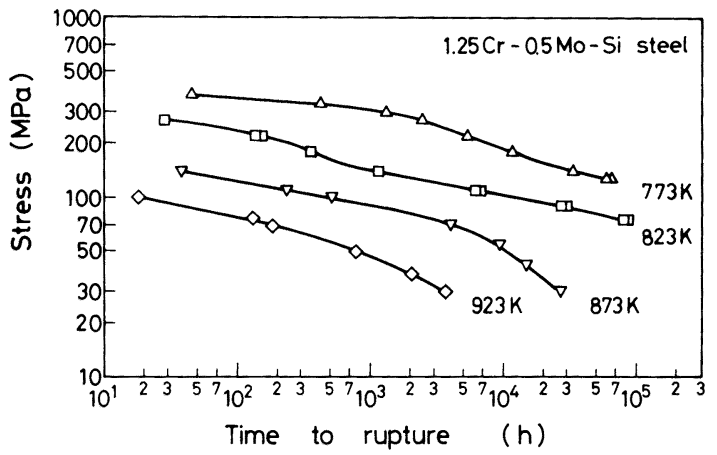

Fig. 5. Stress vs. time to rupture curves of $1.25 \mathrm{Cr}-0.5 \mathrm{Mo}-\mathrm{Si}$ steel at $773,823,873$ and $923 \mathrm{~K}$.



Fig. 6. Creep rate vs. time curves of $1.25 \mathrm{Cr}^{-}$ $0.5 \mathrm{Mo}-\mathrm{Si}$ steel at 773 and $823 \mathrm{~K}$.

る試料の滅肉に対応したものであり，本質的な強度低下 によるものではないと思われる32).

$1.25 \mathrm{Cr}-0.5 \mathrm{Mo}-\mathrm{Si}$ 鋼の 773 及び $823 \mathrm{~K}$ における数応 カレベルでのクリープ速度一時間曲線を Fig. 6 に示す. 通常, クリープ变形は遷移, 定常及び加速の三つの領域, あるいは定常域がなく，遷移及び加速の二つの領域から 形成されると考えられている。しかし，773 K では約 $10000 \mathrm{~h}$ を，また $823 \mathrm{~K} て ゙ は$ 約 $500 \mathrm{~h}$ を超えるとクリー プ速度が再び減少を開始し, 長時間の試験ではクリープ 速度の極小值を二つ示すという複雑な形状を呈してい る.いったんは加速したクリープ速度が再び減少を始め る時間域は，Fig. 5 の応力-破断時間曲線で認められた 長時間側の安定状態へ遷移する時間域とよく対応してい る。このように，従来の概念とは異なり，クリープ速 
度一時間曲線が複雑な形態を呈するという現象は，すで に $\mathrm{KLUEH}^{33) 34)}$ が $2.25 \mathrm{Cr}-1 \mathrm{Mo}$ 鋼で，また坂本ら ${ }^{35)} も$ $2.25 \mathrm{Cr}-1 \mathrm{Mo}$ 鋼, SUS304 及び SUS316 で見出してい る.とくにKLUEH はフェライト系耐熱鋼である 2.25 $\mathrm{Cr}-1 \mathrm{Mo}$ 鋼のクリープ速度一時間曲線でクリープ速度が 二つの極小值を示す点について検討しており，短時間側 が Mo と C の固溶強化に，また，長時間側は針状炭化 物 $\mathrm{Mo}_{2} \mathrm{C}$ の析出分散強化が働くようになることに対応 するものと報告している33134)。しかし，クリープ速度 が再び減少し，二つめの極小值を示す長時間側は，応 力一破断時間曲線の勾配が小さくなる基底強度に達した 時間域に対応している。

そこで，前節の結果に基づいてクリープ速度-時間曲 線が複雑な形状を示す機構について考察した結果を Fig. 7 に示す.これは前節の Fig. 4 の内部応力の変化 とそれに対応したクリープ速度ー時間曲線の形態を模式 的に示したものである。岸化物による析出分散強化量を 一定と仮定した場合のクリープ速度一時間曲線, $\mathrm{ABC}$ と, 長時間側の基底強度に達した場合の曲線 $\mathrm{A}^{\prime} \mathrm{B}^{\prime} \mathrm{C}^{\prime}$ は, ともに四に示すように古典的なクリープ速度一時間曲線 を示すものと考えられる．しかし，高温でのクリープ変 形中に生ずる組織变化すなわち炭化物の粗大化により析 出分散強化量が低下すると, それに対応してクリープ速 度は胀中の $\mathrm{B}$ から $\mathrm{B}^{\prime}$ へ遷移するものと思われる。そ

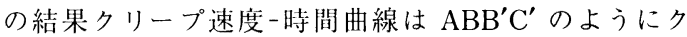
リープ速度の極小值を二つ存する複雑な形状を呈するも のと考えられる.



$\log \cdot t$

Fig. 7. Schematic representation concerning the effect of decrease in creep strength on the morphology of creep rate $v$ s. time curve.

\section{$3 \cdot 3$ フェライト系耐熱鋼の基底強度}

前節では, 忍力-破断時閏曲線が逆 $\mathrm{S}$ 型を示す場令, それに伴いクリープ速度一時䦗曲線は極小值を二つ存す る複雑な形態を示すことを明らかにし，㑒時間側のク リープ変形が穻定な基底強度に対忍するものと推祭し た。したがって，材料の長時間クリープ強度を推定ある いは評価する場合，基底強度に対心した長時閏側でのク リープ破断強度を検討する必要がある.そこで本節では， 数種類のフェライト系耐熱鋼のクリープ強度を比較, 検 討することにより，長時間側の基底強度に達した場命の クリープ破断強度を考察する。

823 及び $873 \mathrm{~K}$ における $0.5 \mathrm{Cr}-0.5 \mathrm{Mo}$ 鋼, $2.25 \mathrm{Cr}$ $1 \mathrm{Mo}$ 鋼及び $1 \mathrm{Cr}^{-}-1 \mathrm{Mo}^{-}-0.25 \mathrm{~V}$ 鋼の心忍了一破断時閣曲線を 併せて Fig. 8 に示す. $823 \mathrm{~K}$ の高心力短時闒側では 3 鋼種のクリープ破断強度は同程度であるが, 忍力の低下 に伴い鋼種による強度差が増大する。これは鋼種により 組織変化の速度が異なり，そのためクリープ強度の低下 の速度が異なるためであると推祭される。

一方，高温側の $873 \mathrm{~K}$ では，3 鋼種の中で最も強度 の低い $0.5 \mathrm{Cr}-0.5 \mathrm{Mo}$ 鋼は約 $1000 \mathrm{~h}$ を超えると曲線の 勾配が小さく直線的になり，長時間側の炎足状態に遷移 している. 2.25Cr-1Mo 鋼は約 $10000 \mathrm{~h}$ を超えると長時 間側の安定状態へ遷移して， $0.5 \mathrm{Cr}-0.5 \mathrm{Mo}$ 鋼のデー夕 の延長線に漸近する。さらに，1Cr-1Mo-0.25V 鋼では 逆 $\mathrm{S}$ 字型の挙動は認められないが, 約 $1000 \mathrm{~h}$ を超える とクリープ破断強度は， $1.25 \mathrm{Cr}-0.5 \mathrm{Mo}-\mathrm{Si}$ 鋼で述べた ように酸化の影響も若十はあろうが急激に低下し，3 鋼

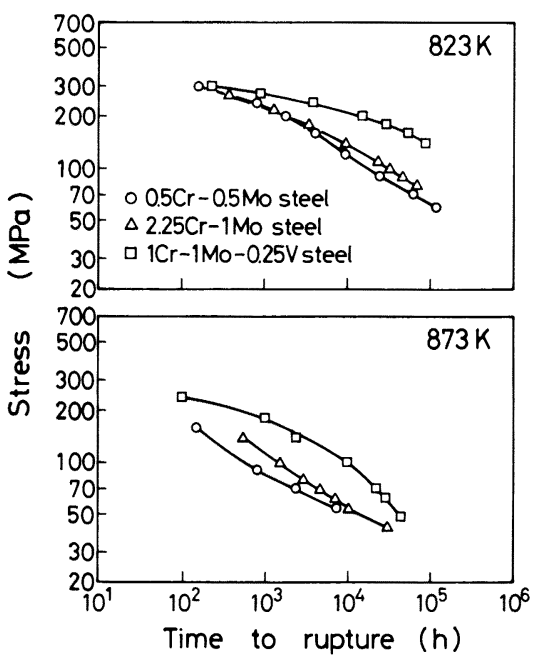

Fig. 8. Stress vs. time to rupture curves of $0.5 \mathrm{Cr}-0.5 \mathrm{Mo}$ steel, $2.25 \mathrm{Cr}-1 \mathrm{Mo}$ steel and $1 \mathrm{Cr}-1 \mathrm{Mo}-0.25 \mathrm{~V}$ steel at 823 and $873 \mathrm{~K}$. 


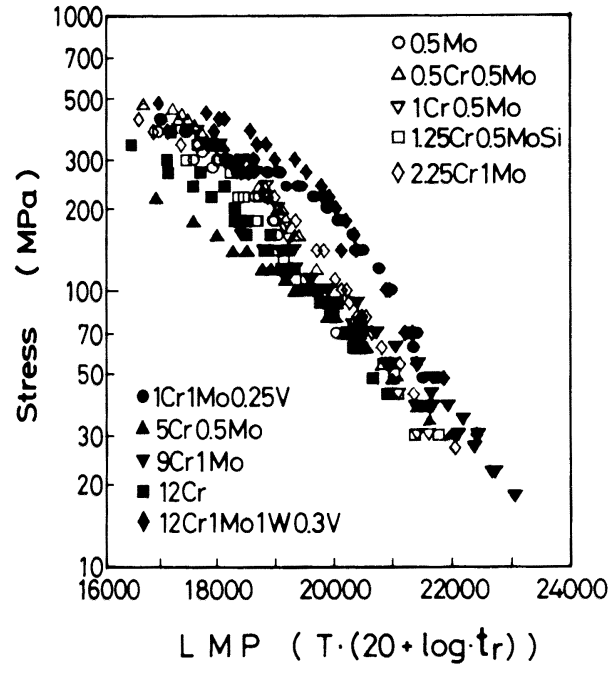

Fig. 9. Relation between stress and LarsonMiller Parameter of ferritic heat resisting steels studied.

種すべての強度がある共通の值に收斂する傾们が認めら れる.

このように， $0.5 \mathrm{Cr}-0.5 \mathrm{Mo}$ 鋼， $2.25 \mathrm{Cr}-1 \mathrm{Mo}$ 鋼及び $1 \mathrm{Cr}-1 \mathrm{Mo}^{-}-0.25 \mathrm{~V}$ 鋼は, 化学:組成, 熱処理及び初期組織 等が巽なるにもかかわらず，高温烓時间側ではクリープ 破断強度の差が減少した。そこで，より広い範网の材料 について長時䦌クリープ呫度を比較することを目的とし て，金材技研クリープデータシートの中から選んだ $\mathrm{Cr}$ 無添加の $0.5 \mathrm{Mo}$ 鋼から最高 $12 \% \mathrm{Cr}$ を含む $12 \mathrm{Cr}^{-} 1 \mathrm{Mo}^{-}$ W-V 鋼まで，10 種類のフェライト系䑧熱鋼を選び出し た。これら 10 種類の条材料について平均的な強度を持 っヒートのクリープデータを抽出し， LMP (兟数 : 20) で整理して Fig. 9 に亦す。低温，短時間側に相当する 汹の左:上オでは鋼種による強度差が大きく，200～300 $\mathrm{MPa}$ の忍カレベルではクリープ破断時間に最高 4 桁程 度の差が認められる。しかし，高温，脙時間側，すなわ ち図の右下方に移行するのに伴い，鋼種による強度差の 程度が小さくなり，金 10 鋼種のデータがある強度レベ ルに収斂する傾们が認められる。すなわち，高温，長時 間の試験中に生ずる組織変化により，鋼種によるクリー プ強度の差は小さくなり，10 鋼種すべての強度がほぼ 同一レベルに到達している.この特性を Fig. 8 の結果 と併せて考祭すると，忍力一破断時閏曲線が逆 $\mathrm{S}$ 字型遷 移を生じた場介、より长時閆側で認められる安定な組織 形態に対伈したクリープ䗐度は，鋼種によらずフェライ 卜系耐熱鋼に共通の基本的なクリープ強度であると考え られる.
以上の結果から，高温での長時間使用に伴って生ずる 組織変化により，フェライト系耐熱鋼は最終的にはある 一定のレベルにまで強度が低下し，その強度が鋼種を問 わずほぼ同じであることが明らかとなった。したがって， 化学組成, 熱処理及び初期組織等の違いにより低温, 䂏 時間側のクリープ強度が異なるのは，最終的な安定状態 である基底強度レベルに到達するまでの組織変化の過程 及び速度が異なるからであり，このような観点から各組 織因子のクリープ強度に及ぼす影響を整理, 評価するこ とにより，フェライト系耐熱鋼のクリープ強度をより的 確に把握することが叮能になるものと思われる。

ところで，フェライト系耐熱鋼に共通の基底強度を決 分する組織因子は，本質的に時間によってその効果の程 度が変化しないものであると思われる。 そこで，基底強 度特性に及ぼす各強化因子の影響としては，以下のよう な点が考えられる。

i)固溶強化

周溶強化はマトリックスの化学組成によって決定され るものであるため, 固溶元素濃度が固溶限以下であり, 析出等によりマトリックスの濃度变化がない場合, その 状態での周溶元素濃度に対忍した固溶強化は基底強度に 影響するものと思われる。

ii)析出強化

析出強化は高温強度を著しく们上させる有効な強化因 子であるが，析出相は高温時効により粗大化し，最終的 には転位のピンニング効果を失うと考えられるので，基 底強度に対して本質的には影響しないと考えられる。

iii)結昆粒径

結晶粒径は高温での長時間使用中において, 比較的变 化しない，安定な組織因子であり，長時闆側の基底強度 に対して影響を及ぼす因子であると思われる。ただし， 熱処理において焼入処理が施され，マルテンサイトある いはベイナイト等の初期組織を有するものは, サブグレ イン化あるいはフェライト粒の形成等により結晶粒径が 大きく変化するので，長時間側の組織形態を的確に把握 することが必要である。

以上のような観点に基づいて，フェライト系耐熱鋼に 共通の基本的なクリープ強度を把握するとともに，それ を決定する組織因子を解明することが今後の最重要課題 であり，有用な余寿命評価法の確立及び長時間使用部材 の信頼性確保につながるものと思われる.

\section{4. 結論}

本研究では, 組織変化に伴う強度低下により応力-破 断時間曲線が逆 S 字型を示すという BOLTON らが提案 
した概念に基づき，金材技研のクリープデータシートの データを用いて，フェライト系耐熱鋼の長時間クリープ 強度特性について検討を行った結果, 以下の結論を得た。

1 )フェライト系の耐熱鋼である $0.5 \mathrm{Cr}-0.5 \mathrm{Mo}$ 鋼の 高温クリープにおいて，応力が約 $100 \mathrm{MPa}$ 以下になる と応力-破断時間曲線の勾配が小さくなり, 逆 $\mathrm{S}$ 字型の 挙動が認められた。

$2) 0.5 \mathrm{Cr}-0.5 \mathrm{Mo}$ 鋼の $823 \mathrm{~K}$ 破断材について組織観 察及びフェライト粒内の硬さ測定を行った結果, 応力一 破断時間曲線で認められた逆 $\mathrm{S}$ 字型の挙動が, 強化機 構，あるいは変形機構の変化に起因するのではなく，析 出炭化物の粗大化に伴う析出強化量の低下及び消失とい う組織変化に伴う強度変化に対応するものと推察した。

3 ) $1.25 \mathrm{Cr}-0.5 \mathrm{Mo}-\mathrm{Si}$ 鋼の応力-破断時間曲線とク リープ速度一時間曲線について検討を行った結果, 応力ー 破断時間曲線に扮いて逆 S 字型の挙動を示す場合，そ れに対応してクリープ速度一時間曲線は二つのクリープ 速度の極小值を有する複雑な形態を示すことを明らかに した。また，長時間側のクリープ速度が長時間側での安 定な組織形態に対応するものと推察した。

4 )化学組成, 熱処理及び初期組織の大きく買なる 10 鋼種のフェライト系耐熱鋼についてクリープ強度を比 較，検討した結果，低温，短時間側ではクリープ破断時 間に最高 4 桁程度の大きな差があるが，高温，長時間側 に移行するのに伴い徐々に鋼種による強度差が小さくな り，全 10 鋼種の強度があるレベルに収斂する傾向が認 められた。

5 ) 以上の結果より，高温での長時間使用に伴う組織 変化により，フェライト系耐熱鋼は最終的にはある一定 のレベルにまでクリープ強度が低下し，それが鋼種を問 わずほぼ同程度であることを明らかにした。化学組成, 熱処理及び初期組織等の違いにより低温, 短時開側のク リープ強度特性が異なるのは, 最終的な安定状態の基底 強度レベルに到達するまでの組織変化の過程及び速度が 異なるからであり，このような観点からフェライト系耐 熱鋼のクリープ強度の基本特性を的確に把握するととも に，共通の基底強度を決定する組織因子を解明すること が今後の最重要課題であると結論した。

\section{文献}

1 ) G. J. P. Buchi, J. H. R. PAGE and M. P. SideY; J. Iron Steel Inst., 203 (1965), p. 291

2 ）行俊照大, 吉川州彦: 学振 123 委研究報告, 15 (1974), p. 125

3 ) G. L. Dunlop and $R . W . K$. Honeycombe: Met. Sci., 10 (1976), p. 124

4) $K . R$. Williams and B. Wilshire: Mater. Sci. Eng., 28 (1977), p. 289

5 ) 中橋昌子, 伊藤昌行, 中村新一, 小松周一, 中山義大: 学振 123 委研究報告, 18 (1977), p. 89

6 ）小松周一, 中村新一, 中橋昌子: 学振 123 委研究報告, 19 (1978), p. 123

7 ) R. A. Stevens and P. E. J. FlewitT: Mater. Sci. Eng., 37 (1979), p. 237

8 ) K. R. Williams and B. J. CANE: Mater. Sci. Eng., 38 (1979), p. 199

9 ) C. J. Bolton, B. F. Dyson and $K . R$. Williams: Mater. Sci. Eng., 46 ( 1980 ), p. 231

10) $K . R$. Williams and B. WilshiRe: Mater. Sci. Eng., 47 (1981), p. 151

11）山田政之，渡辺 修，小松周一，中村新一: 学振 123 委 研究報告, 22 (1981), p. 1

12) L. P. Stoter: J. Mater. Sci., 16 (1981), p. 1039

13）新谷約雄, 横井 信, 京野純郎, 村田正治, 田中秀雄: 学振 123 委研究報告, 22 (1981), p. 189

14）新谷紀雄, 田中秀雄, 具瀬正次, 村田正治, 横井 信: 学振 123 委研究報告, 23 (1982), p. 263

15）川口 要, 柏田 潤, 古田 稔, 堺 松成: 火力原子力 発電, 33 (1982), p. 899

16) J. M. Silcock: Met. Sci., 17 (1983), p. 101

17) R. B. Carruthers and M. J. Col.lins: Met. Sci., 17 (1983), p. 107

18）田中 勝, 半谷文雄, 近藤義宏, 行方二郎: 学振 123 委 研究報告, 24 (1983), p. 373

19）山山泰広，田中 勝，松村智秀，行方二郎，近藤義宏： 鉄と鋼，71 (1985)，S618

20）木村一弘，松尾 孝，㐘池 望，田中高斗：鉄と䤱，72 (1987), p. 474

21）木村一弘: 束京厂:業大学学位論文 (1987)

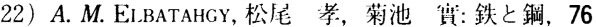
(1990), p. 767

23）横井 信, 門騳義雄: 鉄と䤡，65 (1979), p. 831

24）耳野 亭, 木下和久, 井原義人: 学振 123 委研究報告, 9 (1968) 2, p. 1

25）行俊照夫，西田和彦: 材料, 21 (1972), p. 204

26）横井 信, 新谷紀雄, 田中秀雄: 学拢 123 委研究報告, 15 (1974), p. 113

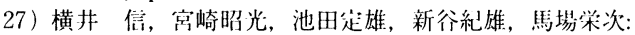
学振 123 委研究報告, 17 (1976), p. 69

28) B. Wal.SER: Met. Sci., 13 (1979), p. 49

29) O. A. Ruano, A. K. Millere and O. D. Sherby: Mater. Sci. Eng., 51 (1981), p. 9

30 ) 角剭好邦, 後藤 徹: 鉄と鋼, 76 (1990), p. 1171

31) S. F. Cl.AeYs and J. W. Jonks: Met. Sci., 18 (1984), p. 432

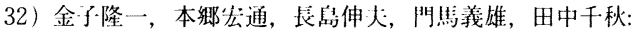
材料とプロセス，1 (1988)，p. 900

33) R. L. KLuEh: Mater. Sci. Eng., 35 (1978), p. 239

34) R. L. Kı.UEH: Metall. Trans. A, 9 (1978), p. 1591

35 ）坂本正雄, 八林筲一, 森下 弘, 久保清, 阴駡義雄, 田中千秋: 材料，39 (1990), p. 674 